\title{
Structural analysis of the national ombudsman activities in ensuring environmental human rights
}

\author{
Mikhail Olenev ${ }^{1, *}$ \\ ${ }^{1}$ Research Institute of the Federal Penitentiary Service of Russia, 15a, building 1, Narvskaya str., \\ 125130, Moscow, Russia
}

\begin{abstract}
In this article, the author examines the organization of the activities of the national ombudsman (Human Rights Commissioner in the Russian Federation) to ensure human rights in the field of ecology, conducts a structural analysis of the received applications from citizens on environmental issues, and also makes a number of proposals to improve the activities of the ombudsman. Based on the results of the study, the main topics of citizens' appeals regarding violations of the rules for the environment use and abuse of environmental human rights submitted to the Commissioner for Human Rights in the Russian Federation were identified. The identification of borderline points by the national ombudsman requires attention in the field of environmental protection of citizens and giving them a public discussion, allows to focus the attention of society and the state on the most problematic aspects of ensuring human rights in the field of ecology, which helps the responsible state authorities to build their work more effectively in this direction, since the state of nature, environment and the ecological situation ultimately affect the development of both individual citizens and society and the state as a whole.
\end{abstract}

\section{Introduction}

The right to a healthy environment today is one of the most important social values. This right is a natural human right, enshrined and guaranteed by both international documents and the Constitution of the Russian Federation. At the same time, this right is enshrined in the Federal Law "On Environmental Protection" and is established as the goal of the state environmental policy. The life, health and well-being of not only a single individual, a living Russian citizen, but also the entire society as a whole, as well as future generations, depends on its provision. Taking into account the current state of the environment and growing environmental problems (waste disposal, pollution of reservoirs and low quality of drinking water, air pollution, etc.), the importance of the right to a enabling environment and a good state of ecology for residents is increasing every year and becomes more relevant. The President of the Russian Federation also draws attention to this in his annual message to the Federal Assembly of the Russian Federation on January 15,

*Corresponding author: a.copytowa@yandex.ru 
2020 , in which he emphasizes that the problems of ecology, climate change, pollution of the environment and World Ocean are common challenges of global development. In the states, various bodies are being created, whose competence also includes protecting the rights of citizens in the field of ecology and preserving the environment. One of such additional bodies and at the same time an effective mechanism of such protection is the national ombudsman.

The purpose of the study is to identify the legal basis for organizing the activities of the Commissioner for Human Rights in the Russian Federation (hereinafter referred to as the Commissioner) in the field of ecology and ensuring the environmental rights of citizens, as well as analysis of citizens' appeals to the Commissioner on this topic. To achieve this goal, it is necessary to solve the following tasks:

- to analyze the norms of law that establish the legal basis for the activities of the Commissioner to ensure the rights of citizens in the field of ecology;

- consider the powers and competence of the Commissioner in the field of ensuring a proper environment;

- to carry out a structural analysis of the subjects of citizens' appeals to the Commissioner in the field of the environmental situation in order to identify problem areas in the field of ensuring human rights to an enabling environment;

- study the statistical information of the national ombudsman for ensuring human rights in the field of ecology.

\section{Methods}

One of the legal guarantees ensuring the proper state of human rights, including in the field of ecology, is the Commissioner. The creation and operation of the national ombudsman has been the subject of research by various scholars. So, Yunusov A.A. and Yunusov S.A. define the legal institution of the Commissioner for Human Rights as an additional legal guarantee to the existing methods of protecting human rights [1]. Conceptual approaches to organizing the activities of the Commissioner were considered by Barandova T.L. [2]. The theoretical substantiation of the organization of the activities of the Commissioner in dissertation research was studied by Korabelnikova Yu.L. (Moscow, 2007) [3], Skorobogatova O.V. (Moscow, 2013), Kalinina E.G. (Yekaterinburg, 2016) [4] and others. Problems in the field of environmental protection and the rights of citizens to an enabling environment were considered by Chulichkova E.V., Nizhnik L.S. [5].

There are other scientifical studies related to the protection of the environment and ensuring the rights of citizens to a proper environment, however, the problem of ensuring human rights in the field of nature remains quite relevant and topical, since the Commissioner is regularly approached on this issue. Moreover, it should be noted that the contribution of the ombudsman to the protection of the right of citizens to a healthy environment and other environmental rights is practically not considered in the legal literature.

The research methodology is built on the basis of an analysis of the current legislation, theoretical provisions and practice of organizing the activities of the Commissioner for ensuring human rights in the field of ecology. The research was based on such methods as dialectical, logical, statistical, comparative-legal, analysis, synthesis, etc.

\section{Results}

The establishment of the institution of the Ombudsman as a state body is one of the significant achievements of democratic transformations in Russia. This is an important 
mechanism for protecting human rights (including in the field of ecology) and strengthening the rule of law in the activities of state bodies and their officials. It is characterized by an independent position in the system of state bodies, openness and accessibility for all citizens who need to protect their rights and freedoms, the absence of formalized procedures for handling complaints and appeals, free assistance to citizens, etc.

The study showed that the Ombudsman is actively involved in identifying and restoring violated environmental rights of citizens, for example: the right to a favorable environment, reliable information about its condition (air, water bodies) and to compensation for damage caused to human health or property by an environmental offense. It seems that the condition for the effective protection of citizens' right to an enabling environment in the long term is primarily information and legal education in the field of ecology. In this regard, it is advisable to consider the possibility of making changes to educational programs in terms of their addition with a special module on the environmental legal framework, which provides for the knowledge and ability to exercise rights and comply with obligations in the field of environmental protection. Problems are often multifaceted and repetitive because of being unresolved or neglected. There is also a clear need to create a full-fledged environmental monitoring system for the operational tracking of problematic issues in the field of ecology and ways to solve them.

\section{Discussion}

Nikiforos Diamandouros, using the example of the European Ombudsman, sees the role of the Ombudsman in the supervision of the European Union bodies ensuring the observance of human rights in the field of the environment, where the effectiveness of such supervision is ensured primarily by an effective internal procedure for filing complaints for applicants before they turn to the Ombudsman [6]. Most environmental complaints to the Ombudsman concern the responsibility of the European Commission to ensure that member states comply with their obligations under European Union law. When organizing the work of the Ombudsman, Gottehrer D. highlights such important qualities as independence, impartiality, fairness; reliable process, confidentiality [7]. Galang Asmara believes that the very existence of the ombudsman institution serves as a way to protect the rights of citizens from an act of unfair administration, and its presence is mandatory [8]. From the position of Nikos Vogiatzis, the Ombudsman is the main instrument of political pressure, with the help of annual reports it is possible to convey to a wide audience the results of the past year and the main problems with ensuring human rights [9]. Nabila F.I. defines the Ombudsman as an public official who helps manage public services and who plays an important role in the delivery of efficient and effective public services. [10] Mirlinda Batalli highlights the role of the Ombudsman in enhancing accountability, efficiency, transparency in public administration and promoting higher levels of protection of human rights, including in the penitentiary sphere [11].

According to Defne Gönenç, environmental protection must be built with human rights in mind. Linking norms derived from different problem areas is achieved through the constant use of strategic frameworks derived from different problems, acceptance of the norm by society and action in accordance with the new norm [12]. David Androff believes that it is necessary to promote the protection of environmental rights, especially in training, since this block should be included in the curriculum [13].

Thus, the majority of scientists support the concept that the Commissioner is, first of all, a public authority with certain powers. The range of competences of the Environmental Protection Commissioner may vary, starting only from a review of a problematic situation, and ending with bringing relevant materials to law enforcement agencies. There is more and more understandable in modern society that there is the importance not only of 
protecting the environmental rights of citizens with the help of the Commissioner or various state bodies, but also the need to teach these rights to citizens during the period of education.

It is known that the rights and freedoms of a person and a citizen provided for by the Constitution of the Russian Federation and sectoral legislation should not only be proclaimed, but also protected and guaranteed by the state. The state must create conditions for citizens to freely and unimpeded exercise their rights, and in the event of their violation, they can restore them. In this connection, the full realization of the right to an enabling environment is impossible without the activities of state bodies, since it is they who must create the conditions for ensuring, realization, protection and protection of the right to an enabling environment.

The institution of the Ombudsman is defined by the International Bar Association as «a service provided for by the constitution or by an act of the legislature and headed by a highranking independent public official who is accountable to the legislature, receives complaints from injured persons against government agencies, employees, employers or acts in its sole discretion and conduct investigations, recommend corrective actions and submit reports» [14].

The regulatory and legal main organization of the activities of the Commissioner in the field of ecology is the Constitution of the Russian Federation, Federal Constitutional Law of February 26, 1997 No.1-FCL "On the Commissioner for Human Rights in the Russian Federation" (hereinafter FCL No.1), Federal Law of January 10, 2002 No.7-FL (Federal Law)"On environmental protection". The documents of strategic planning in the field of preserving an appropriate environmental situation include the Decree of the President of the Russian Federation of January 16, 2017 No.13 "On the approval of the Fundamentals of the state policy of regional development of the Russian Federation for the period up to 2025" and etc.

According to Art. 1 of FCL No.1, the position of the Commissioner was established in order to ensure guarantees of state protection of the rights and freedoms of citizens, their observance and respect by state bodies, local self-government bodies and officials. The Commissioner promotes the restoration of violated rights, improvement of the legislation of the Russian Federation on human and civil rights and bringing it into line with generally recognized principles and norms of international law, the development of international cooperation in the field of human rights, legal education on human rights and freedoms, forms and methods of their protection.

The legal status of the Commissioner, among other things, is characterized by independence and non-accountability to any state bodies and officials. He is not endowed with powers of authority, directive measures of influence on state and other bodies and officials, does not adopt legal acts. However, the current laws provide for a wide range of responsibilities of state bodies and officials in relation to the actions and appeals of the Ombudsman, such as: providing assistance, providing information, necessary materials, giving explanations on issues to be clarified during the consideration of complaints, etc. The activities of the Ombudsman supplement the existing means of protecting the rights and freedoms of citizens, does not cancel and does not entail a revision of the competence of state bodies that ensure the protection and restoration of violated rights and freedoms. However, the problematic moments that the Ombudsman finds during the consideration of citizens' appeals on the state of the environment help to identify the most priority areas for the state's work to improve the law enforcement mechanism in the field of ensuring a favorable environment.

Based on the study of the annual and special reports of the Commissioner, one can judge the state of work to ensure the environmental rights of citizens. 
In 2020, the Commissioner received 44,087 complaints from citizens [15]. Of these, 274 appeals were made on issues related to the legislation on environmental protection (see Table 1).

Table 1. Indicator.

\begin{tabular}{|l|c|c|c|}
\hline Year & $\mathbf{2 0 1 8}$ & $\mathbf{2 0 1 9}$ & $\mathbf{2 0 2 0}$ \\
\hline $\begin{array}{l}\text { Number of appeals on issues related to } \\
\text { environmental protection legislation }\end{array}$ & 411 & 341 & 274 \\
\hline
\end{tabular}

Despite the decrease in the number of applications received in 2020 on issues related to environmental protection legislation (in comparison with 2019, it decreased by $20 \%$, and since 2018 - decreased by 33\%) and their low share in the total number of applications received by the Commissioner, the significance of the problems raised in them remains extremely high, since in most cases, violations of rights in the field of ecology affect an indefinite circle of people.

Every twentieth of the applications received in 2020 was collective (1910 applications in total). At the same time, even in individual appeals to the Ombudsman regarding the protection of the right to a healthy environment, violations are often reported that affect the rights of hundreds and thousands of citizens.

The massive nature of violations of the rights of citizens in the field of ecology determines the results of consideration of individual appeals to the Ombudsman on these issues. Thus, in 2018, over 87,000 citizens' rights to an enabling environment were restored based on only 15 complaints; in 2017, the rights of more than 200 thousand people were restored only on 12 complaints.

In total, in 2020, the Ombudsman received 993 applications on the implementation of the right to an enabling environment and the implementation of land rights, which is $15 \%$ less than in 2019 and 38\% less than in 2018. 126 requests were collective, which is significantly less than in 2019 (162). Most of them dealt with issues of compliance with environmental requirements in urban planning activities and the resolution of land disputes. The decrease in the number of appeals was mainly due to complaints about the operation of municipal solid waste landfills (see Table 2).

Table 2. Indicator.

\begin{tabular}{|l|c|c|c|}
\hline Year & $\mathbf{2 0 1 8}$ & $\mathbf{2 0 1 9}$ & $\mathbf{2 0 2 0}$ \\
\hline $\begin{array}{l}\text { The number of applications on the } \\
\text { implementation of the right to an enabling } \\
\text { environment and the implementation of land } \\
\text { rights }\end{array}$ & 1609 & 1361 & 993 \\
\hline
\end{tabular}

The main part of the group under consideration was made up of appeals on land protection issues. In 2020, the Commissioner received 504 such applications, which is $44 \%$ less than in 2018. The applicants pointed to the facts of misuse of land plots, which led to their degradation, wasteful use of land, ineffective state land supervision and municipal land control. In addition, complaints were received in connection with the contamination of land plots during the placement and operation of industrial facilities, waste processing complexes, and the use of harmful fertilizers (see Table 3).

Table 3. Indicator.

\begin{tabular}{|l|c|c|c|}
\hline Year & $\mathbf{2 0 1 8}$ & $\mathbf{2 0 1 9}$ & $\mathbf{2 0 2 0}$ \\
\hline $\begin{array}{l}\text { Number of applications on land protection } \\
\text { issues }\end{array}$ & 906 & 699 & 504 \\
\hline
\end{tabular}

Every fifth appeal on the implementation of the right to a healthy environment related to the protection of atmospheric air. In 2020, the Ombudsman received 137 such appeals, 
which is $40 \%$ less than in 2018. Within the framework of this topic, complaints were received in connection with the problems of compliance with the requirements of legislation in the field of production and consumption waste management. Citizens expressed concern about the construction or operation of waste processing plants and solid waste landfills, the placement of unauthorized dumps, reported non-compliance with the requirements for storage and disposal of solid waste, and pointed to the unjustified procedure for setting tariffs for garbage disposal.

Violations of the requirements of sanitary and epidemiological legislation, resulting in air pollution, including exceeding the maximum permissible concentration of pollutants, remain a widespread problem in the field of atmospheric air protection (see Table 4).

The situation with increased air pollution in industrial regions and large cities remains a serious environmental problem. Unfortunately, the current urban planning legislation lacks effective legal mechanisms for taking environmental factors into account when making urban planning decisions, which leads to the approval of insufficiently substantiated urban planning documents that directly violate the rights of the local population and property owners. According to the Accounts Chamber of the Russian Federation, 56 million people in 143 cities live in polluted air in the country, while air pollution increases with climate change, since meteorological conditions prevent the dispersion of impurities [16].

Table 4. Indicator.

\begin{tabular}{|l|c|c|c|}
\hline Year & $\mathbf{2 0 1 8}$ & $\mathbf{2 0 1 9}$ & $\mathbf{2 0 2 0}$ \\
\hline $\begin{array}{l}\text { Number of applications on the protection } \\
\text { of atmospheric air }\end{array}$ & 226 & 191 & 137 \\
\hline
\end{tabular}

There were complaints about the preservation of the forest fund. In 2020, the Ombudsman received 36 such appeals, which is $70 \%$ more than in 2018 . The number of these appeals is not large, but the topics raised in them are no less ambitious than other areas of nature protection. They reported on illegal cutting of green spaces, as well as violations related to the transfer of forest lands to other categories. Some of them were collective and acute (see Table 5).

Table 5. Indicator.

\begin{tabular}{|l|c|c|c|}
\hline Year & $\mathbf{2 0 1 8}$ & $\mathbf{2 0 1 9}$ & $\mathbf{2 0 2 0}$ \\
\hline $\begin{array}{l}\text { Number of appeals on issues of forest } \\
\text { fund conservation }\end{array}$ & 21 & 28 & 36 \\
\hline
\end{tabular}

The appeals related to the protection of water bodies related to the observance of the regime of sanitary protection of the coastal strip, restriction of access of citizens to water bodies, as well as their pollution as a result of non-compliance by industrial enterprises with the requirements of environmental legislation. Such violations lead to large-scale environmental disasters. In 2020, the Ombudsman received 34 such appeals, which is $38 \%$ less than in 2018 (see Table 6).

Table 6. Indicator.

\begin{tabular}{|l|c|c|c|}
\hline Year & $\mathbf{2 0 1 8}$ & $\mathbf{2 0 1 9}$ & $\mathbf{2 0 2 0}$ \\
\hline $\begin{array}{l}\text { Number of appeals related to the } \\
\text { protection of water bodies }\end{array}$ & 55 & 48 & 34 \\
\hline
\end{tabular}

Thus, the Commissioner acts as a non-judicial form of legal protection and restoration of violated human rights and freedoms [17], including the sphere of ensuring the environmental rights of citizens. A feature of the Ombudsman is his almost complete absence of any "power" functions and coercive powers. He does not make state-power decisions and his activity does not cancel and does not entail a revision of the competence 
of state bodies. His main "weapon" is to draw attention, first of all, to the state, to the problem of environmental protection and environmental rights of citizens by publishing annual and special reports, meetings, interviews with the media, speeches in parliament, etc.

\section{Conclusion}

The right to a favorable environment is collective, affects the interests of an indefinite circle of people, the adverse consequences of violation of this right are often difficult to individualize. In this regard, the provision of federal legislation contributes to effective protection of the right to an enabling environment, according to which information on violations of citizens' rights can be obtained by the Commissioner not only from applications, but also from the media.

Human rights, including in the field of ecology, need constant protection. The Ombudsman helps prevent violations of legal human rights, and, if necessary, helps restore them. The necessary legal basis for this has been created, and the scope of powers within the framework of the functioning of the ombudsman institution in the field of ensuring the rights of citizens in the field of ecology is also standard for this state body.

Analysis of the appeals received by the Commissioner makes it possible to highlight the main problems of protecting the right of citizens to a healthy environment: problems of utilization of production and consumption waste; the impact of the construction of industrial, waste processing plants, sewage facilities on the environmental situation; pollution of water bodies, issues of ensuring the protection of water bodies and access of the population to clean drinking water; air pollution by emissions from stationary sources (industrial enterprises, landfills); issues of preserving the forest fund; improper control over the use and protection of land; unsatisfactory state of ecology (for environmental pollution) in settlements, etc.

Thus, the right of everyone to a healthy environment is one of the fundamental human rights and implies real opportunities to live in a healthy environment that meets international and state standards. This right acts as an innate, immanently inherent quality of a person. The right to an enabling environment is one of those rights and freedoms, the totality of which makes it possible to judge the position of an individual in a particular society, as well as the characteristics of the state. Moreover, the successful implementation of this right creates the necessary conditions for the realization of all other human rights, freedoms and interests.

\section{References}

1. A.A. Yunusov, S.A. Yunusov, Human: crime and punishment 2, 132-135 (2013)

2. T.L. Barandova, Journal of Social Policy Research 4(10), 505-520 (2012)

3. Yu.L. Korabelnikova, Constitutional and legal foundations of interaction between the Commissioner for Human Rights in the Russian Federation and executive authorities in ensuring constitutional rights and freedoms of man and citizen: dis. candidate of legal sciences (Moscow, 2007)

4. O.V. Skorobogatova, Protection of the rights of persons held in penitentiary institutions, regional ombudsman for human rights: abstract dis. candidate of legal sciences (Moscow, 2013)

5. E.G. Kalinina, Specialized ombudsmen for human rights in Russia and abroad: comparative legal research: dis. candidate of legal sciences (Yekaterinburg, 2016) 
6. E.V. Chulichkova, Constitutional and legal mechanism for ensuring the right of everyone to a healthy environment in the Russian Federation: dissertation candidate of legal sciences (Yekaterinburg, 2018)

7. L.S. Nizhnik, Organizational and economic and legal guarantees for the implementation of the right to a favorable environment: diss. candidate of legal sciences (Moscow, 2019)

8. Diamandouros P. Nikiforos, Monitoring our impact on the environment: the role of Ombudsmen (2011) https://www.ombudsman.europa.eu/en/speech/en/10558.

9. D. Gottehrer, IOI Stockholm conference: Plenary Session II: Developing the Working Methods and Tools of the Ombudsman (2009) http://www.theioi.org/publications/stockholm-2009-conference-papers.

10. A. Galang, Mediterranean Journal of Social Sciences 8(5) (2017)

11. V. Nikos, Journal of contemporary European research 10(1) (2014)

12. F.I. Nabila, Jurnal SASI 26(2), 176 - 187 (2020)

13. B. Mirlinda, Academic Journal of Business, Administration, Law and Social Sciences 1(3) (2015)

14. D. Gönenç, Conceptualizing norm fusion through environmental rights (2020) https://www.tandfonline.com/doi/full/10.1080/09644016.2020.1743610

15. D. Androff, Journal of Social Work Education 53(3) (2017)

16. V.V. Komarova, State and law 9, 21 - 31 (1999)

17. Report of the Commissioner for Human Rights in the Russian Federation for 2020 (M, 2021)

18. Thematic report of the Commissioner for Human Rights in the Russian Federation "The Right to the Environment in the Russian Federation" (M., 2019)

19. Report on the results of the expert and analytical event "Monitoring the implementation of the activities of the national project" Ecology ", including the timeliness of their financial support, achievement of goals and objectives, milestones, as well as the quality of management" (2020) http://audit.gov.ru/activities/control/\%D0\%AD\%D0\%BA\%D0\%BE\%D0\%BB\%D0\%B E\% D0\% B3\% D0\% B8\% D1\% 8F\% 202020 -01-15\% 20.pdf

20. E.A. Yunusov, M.G. Olenev, Law and state: theory and practice 1(181), 258-259 (2020)

21. V.F. Lapshin, S.A. Korneev, R.V. Kilimbaev, IOP Conference Series: Materials Science and Engineering 1001, 012144 (2020) DOI: 10.1088/1757899X/1001/1/012144. 